\title{
DETERMINATION OF SEVERAL BITLIS HONEYS BASED ON THEIR BOTANIC AND BIOCHEMICAL PROFILES
}

\author{
BITTLIS YÖRESINDEN ALINAN BAZI BALLARIN BOTANIKK VE BIYYOKIMYASAL \\ PROFILI
}

\section{İlginç KIZILPINAR TEMIZERR ${ }^{1, *}$, Aytaç GÜDER ${ }^{1}$, Birol BAŞER ${ }^{2}$}

${ }^{1}$ Giresun University, Vocational High School of Health Services, Giresun, Turkey

${ }^{2}$ Bitlis Eren University, Faculty of Science and Art, Department of Biology, Bitlis, Turkey

\begin{abstract}
Objective: In this paper, we aimed to evaluate the pollen composition and antioxidant activity of 4 randomly selected honey samples from the Bitlis region in 2017.

Material and Method: The melisopalynological analysis was used standard protocol without acetolysis. The antioxidant activity of samples were evaluated using several in vitro methods, 1,1-diphenyl2-picrylhydrazyl free radical scavenging activity (DPPH), hydrogen peroxide scavenging activity (HPSA), Ferrous ions chelating activities (FICA), 2,2'-azino-bis-3-ethylbenzthiazoline-6-sulphonic acid radical cation scavenging assays (ABTS) and the ferric reducing antioxidant power assays (FRAP).

Result and Discussion: All the samples were determined as multifloral honey. Outcomes obtained declared that the antioxidant activity changed remarkably from honey to honey. ABTS and FICA of samples differ slightly each other's. DPPH, HPSA, and FRAP were ranged from between $54.45-387.60 \mu \mathrm{g} / \mathrm{mL}$, $212.11-246.64 \mu \mathrm{g} / \mathrm{mL}$ and $47.20-78.23 \%$, respectively. In addition, total phenol and total flavonoid contents were determined. Comparatively, Sample 3 showed highest levels of phenolic and flavonoid content (626.48 mg GAE/100 $\mathrm{g}$ and $4.4 \mathrm{mg} C A E / 100 \mathrm{~g}$, respectively) in ethanol extract. Almost all the samples are well source for antioxidants.

Keywords: Antioxidant, ethanol, multiflora, palynology

\section{$\ddot{\mathbf{O Z Z}}$}

Amaç: Bu makalede 2017 yulında Bitlis bölgesinden rastgele seçilen 4 bal örneğinin polen kompozisyonunu ve antioksidan aktivitesini değerlendirmeyi amaçladık.

Gereç ve Yöntem: Melisopalinolojik analizde asetolizsiz standart protokol kullanılmıştır. Numunelerin antioksidan aktivitesi, 1,1-difenil-2-pikrilhidrazil serbest radikal giderme aktivitesi (DPPH), hidrojen peroksit giderme aktivitesi (HPSA), demirli iyon şelat aktiviteleri (FICA), 2,2'-azino-bis-3-etilbenztiyazolin-
\end{abstract}

\footnotetext{
* Corresponding Author/Sorumlu Yazar: İlginç Kızılpınar Temizer e- mail/e-posta: ilginc.kizilpinar@giresun.edu.tr
} 
6-sülfonik asit radikal katyon temizleme deneyleri (ABTS) ve ferrik indirgeyici antioksidan güç deneyleri (FRAP) gibi birkaç in vitro yöntem kullanılarak değerlendirilmiştir.

Sonuç ve Tartışma: 4 balın polen kompozisyonu değerlendirildiğinde balların multifloral olduğu görülmüş̧ür. Elde edilen sonuçlar, antioksidan aktivitesinin baldan bala belirgin bir şekilde değiştiğini göstermiştir. ABTS ve FICA örnekleri birbirlerinden biraz farkl, DPPH, HPSA ve FRAP sirastyla 54.45 $387.60 \mathrm{ug} / \mathrm{mL}, 212.11$ - $246.64 \mathrm{ug} / \mathrm{mL}$ ve \% 47.20 - 78.23 arasinda bulunmuştur. Ek olarak, toplam fenol ve toplam flavonoid içerikleri belirlenmiştir. Örnekler klyaslandığında 3, en yüksek fenolik ve flavonoid içeriği (626.48 mg GAE / $100 \mathrm{~g}$ ve $4.4 \mathrm{mg} \mathrm{CAE} \mathrm{/} 100 \mathrm{~g}$-etanol) göstermiştir. Hemen hemen tüm numunelerin iyi bir antioksidan kaynă̆l olduğu tespit edilmiştir.

Anahtar Kelimeler: Antioksidan, etanol, multifloral, palinoloji

\section{INTRODUCTION}

Honey is sweet solution that consists of fructose, glucose and sucrose but also contains other natural macro- and micro-nutrients [1]. Each honey has unique different characteristics [2]. The physical and biochemical properties of honey are affected by the plant composition of the region where the hives are located [2-4]. Bitlis is located at the Irano-Turanian floristic region which has plentiful plant biodiversity. Asteraceae, Fabaceae, Poaceae Caryophyllaceae, Ranunculaceae and Brassicaceae in Bitlis are seen most commonly families. In addition, Alyssum L., Centaurea L., Astragalus L., Trifolium L., Vicia L, Ranunculus L., Veronica L., Gypsophylla L., and Silene L. are widely present genus [5-9]. These taxa constitute very important nectar and pollen sources for honey bees of Bitlis region. However, there are few reports about botanic origins on honeys from Bitlis.

Honey is the most widely produced and consumed in the worldwide since ancient times. It has been used different purpose such as therapy and food because of its strong antioxidant capacity [1].

Antioxidant compounds play a crucial factor in the defence act of living against pathogens. Antioxidants protect our body against the harmful effects of free radicals by giving a hydrogen atom and a single electron or with various mechanisms such as metal chelating feature [10]. In this study, in order to show the antioxidant profile of honey samples, DPPH free radical scavenging activity, metal-chelate activity, hydrogen peroxide scavenging activity, ABTS radical cation scavenging activity, ferric reducing antioxidant power, as well as total phenolic and flavonoid substance contents that play a very important role in antioxidant capacity were detected.

Beekeeping in Bitlis is varying from amateur to career, becoming always more creative, technical and generative. For this, there is still a lot to learn and develop related to the properties and structures of bee products. However, there is not enough scientific knowledge about the botanic origin and antioxidant activity of Bitlis honey. The goal of this study is the estimation of botanic origin, total phenolic, total flavonoid content, and antioxidant properties of honey produced in Bitlis. 


\section{MATERIAL AND METHOD}

\section{Honey samples}

The study was done on 4 honeys collected directly from beekeepers of Bitlis in 2017 (Figure 1). The botanical origin of the honey samples was approved by melisopalynological examination.

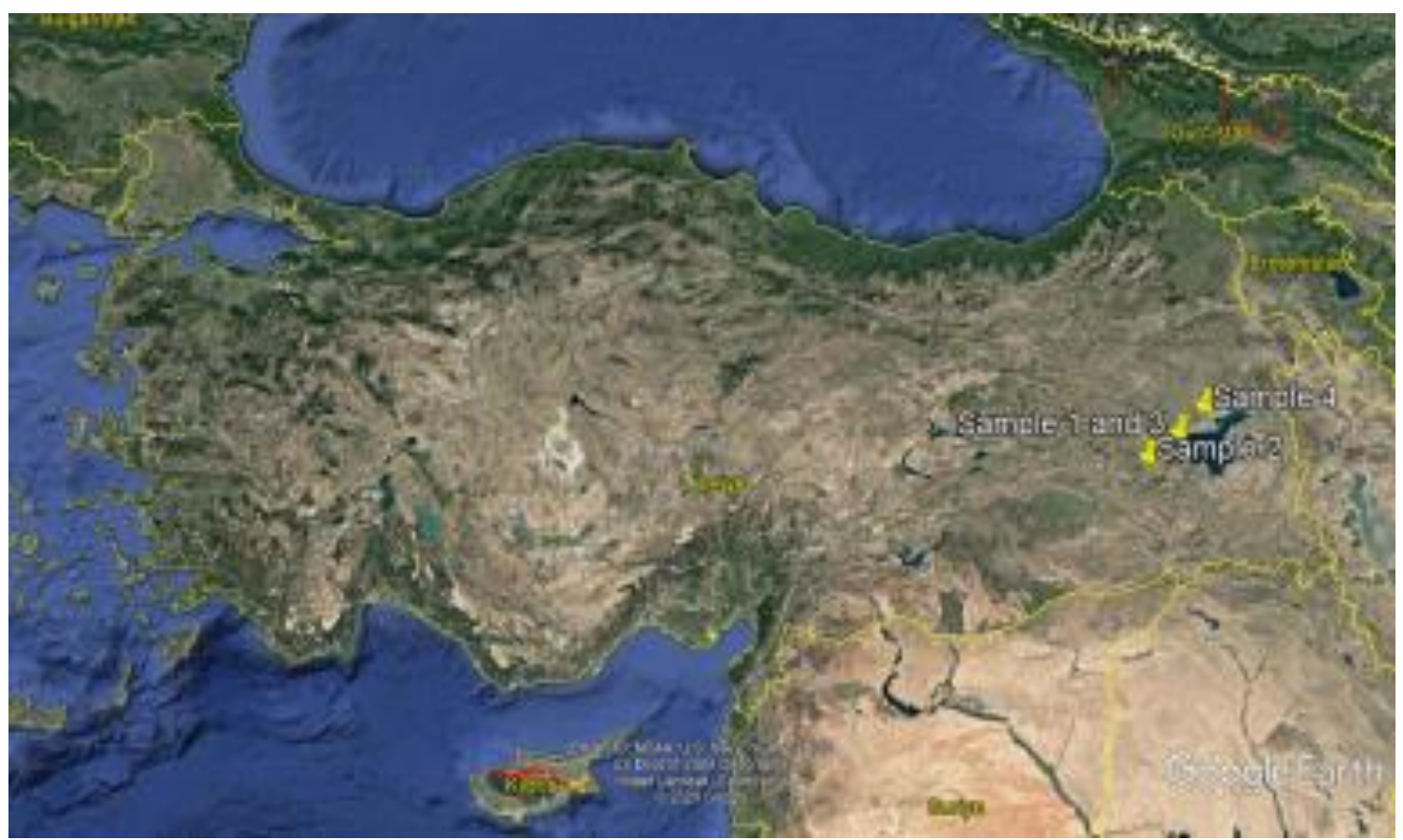

Figure 1. Location of honey samples collected from Bitlis (Google Earth)

\section{Palynological analysis}

A $10 \mathrm{~g}$ sample of each honey was done following scientifically accepted method without acetolysis [11]. The botanic classifications of each honey sample were carried out by microscopic pollen analysis. The terms were allocated for frequency classes: predominant pollen $(>45 \%)$, secondary pollen $(16-45 \%)$, important minor pollen $(3-15 \%)$ and trace pollen $(<3 \%)$ [12]. The following equation (Eq. 1) was used to declare the frequency per taxon.

$$
\text { Frequency }(\%)=\frac{\text { Total number of pollen of a particular species }}{\text { Total number of observed pollen }} \times 100
$$

\section{Antioxidant analyses}

A $10 \mathrm{~g}$ of honey was added to $50 \mathrm{~mL}$ of distilled water and kept in a water bath until the honey dissolved. Finally, total volumes are adjusted to $100 \mathrm{~mL}$ by using distilled water. All the reagents and chemicals used in the experiments were of analytical grade. 


\section{TFC assays}

Total flavonoid contents of samples were done via colorimetric method with minor modifications [13]. In this assay, sample solutions $(0.5 \mathrm{~mL})$ were mixed with $1.5 \mathrm{~mL}$ of pure ethanol. And then $\mathrm{AlCl} 3.6 \mathrm{H} 20(0.1 \mathrm{~mL}, 10.0 \%)$ and potassium acetate $(0.1 \mathrm{~mL}, 1.0 \mathrm{~mol} / \mathrm{L})$ were added. Distilled water was used for bringing the total volume to $5.0 \mathrm{~mL}$. $30 \mathrm{~min}$ later, the absorbance values were read at $415 \mathrm{~nm}$. The found results were calculated as $\mu \mathrm{g}$ catechin equivalent by using catechin standard calibration graphic $(\mathrm{R} 2=0.9979)$.

\section{TPC assays}

Total phenolic content assays were performed according to previous method [14]. For this assay, sample solutions $(0.5 \mathrm{~mL})$ were added to distilled water $(7.0 \mathrm{~mL})$ and Folin $\mathrm{C}$ reagent $(0.5$ $\mathrm{mL}$ ), respectively. 3 min later, sodium carbonate solution $(3.0 \mathrm{~mL}, 2.0 \%)$ was mixed with this solution. Colour change expected during $1 \mathrm{~h}$ and the absorbance values were recorded at $760 \mathrm{~nm}$. For evidence of the total phenolic contents, standard Gallic acid graphic was used (R2=0.9995).

\section{DPPH assays}

The DPPH radical scavenging activity assays were carried out according to previous method with minor modifications [15]. For this reason, the diluted samples $(3.0 \mathrm{~mL})$ at the varied concentrations $(10-100 \mu \mathrm{g} / \mathrm{mL})$ were mixed with stable DPPH radical solutions $(1.0 \mathrm{~mL}, 0.2 \mathrm{mM}$ in ethanol). The mixtures were shaken vigorously and left to stand for $30 \mathrm{~min}$ at RT and in an unlit environment. Finally, absorbance values were measured $517 \mathrm{~nm}$. The radical scavenging activity results were evaluated as $\mathrm{SC} 50(\mu \mathrm{g} / \mathrm{mL})$.

\section{HPSA assays}

The hydrogen peroxide scavenging activities of samples were tested out by using spectrophotometric method described by Ruch et al. (1989) [16]. According to this method, the samples $(3.4 \mathrm{~mL})$ were added to hydrogen peroxide $(0.6 \mathrm{~mL}, 40 \mathrm{mM})$. The results were given as SC50 values $(\mu \mathrm{g} / \mathrm{mL})$ with absorbance values at $230 \mathrm{~nm}$.

\section{FICA assays}

Ferrous ions chelating activities were examined by using previous method [17] with slowly modifications. Briefly, the tested solutions $(0.4 \mathrm{~mL})$ added to $\mathrm{FeCl} 2$ solution $(0.05 \mathrm{~mL}, 2 \mathrm{mM})$ and kept at the room temperature for $10 \mathrm{~min}$. Finally, ferrozine solution $(0.2 \mathrm{~mL}, 5 \mathrm{mM})$ and pure ethanol $(3.3 \mathrm{~mL})$ were mixed with this solution, respectively and all tubes were vortexed about $5 \mathrm{~min}$. After these mixing processes, absorbances were recorded at $562 \mathrm{~nm}$ and FICA values were expressed as 
activity $(\%)$.

Ferrous Ions Chelating Activity $(\%)=[1-(\mathrm{As} / \mathrm{Ac})] \times 100$

\section{ABTS assays}

ABTS radical cation scavenging assays were performed via spectrophotometric method [18]. In this experimental method, ABTS $(2.0 \mathrm{mM})$ and potassium persulfate $(2.45 \mathrm{mM})$ was stirred to product ABTS •+. The fresh prepared solution was stand up for $16 \mathrm{~h}$ at room temperature and in an unlit environment. The absorbance of this solution was fixed to $0.750 \pm 0.020$ at $734 \mathrm{~nm}$. Therefore, dilution process was realized by using the PBS $(0.1 \mathrm{M} \mathrm{pH}$ 7.4). The obtained ABTS radical cation solution is stable for 2 days. For determination of activity, the adjusted ABTS $\bullet+(1.0 \mathrm{~mL})$ was added to serially diluted sample solutions $(3.0 \mathrm{~mL})$ at the different concentrations $(1-10 \mu \mathrm{g} / \mathrm{mL}$ in PBS). The activities were enounced as SC50 values $(\mu \mathrm{g} / \mathrm{mL})$.

\section{FRAP assays}

The ferric reducing antioxidant power assays were exerted according to Oyaizu method [19] with minor modifications. Firstly, PBS ( $2.5 \mathrm{~mL}, \mathrm{pH} 6.6,0.2 \mathrm{M})$ and potassium ferricyanide $(2.5 \mathrm{~mL}$, $1.0 \%)$ were stirred with samples $(2.5 \mathrm{~mL})$, respectively. Later, the coloured mixture solutions were incubated for $20 \mathrm{~min}$ at $50^{\circ} \mathrm{C}$. Then, TCA $(2.5 \mathrm{~mL}, 10 \%)$ were mixed with this solution. Lastly, this solution $(2.5 \mathrm{~mL})$ was stirred with $\mathrm{FeCl} 3(0.5 \mathrm{~mL}, 0.1 \%)$ and distilled water $(2.5 \mathrm{~mL})$. The absorbance value of the obtained solution was recorded at $700 \mathrm{~nm}$. The ferric reducing antioxidant power results were given as $\%$.

$$
\operatorname{FRAP}(\%)=(\mathrm{As} / \mathrm{Ac}) \times 100
$$

\section{RESULT AND DISCUSSION}

The detected pollen types and their taxa were summarised in Table 1. According to the palynological analysis 16 families, 19 genus and 3 pollen types in samples were identified and detected no predominant taxa. Onobrychis Adans., Trifolium L. and Vicia L. were observed as seconder group. In addition, the frequently observed pollens were belonging to Asteraceae, Brassicaceae, Boraginaceae, Cistaceae and Fabaceae families. These families were in agreement with Bitlis vegetation and were generally consist of melliferous plants. The taxa determined in samples match the results declared by other authors for botanic origin of honeys [20-22] 
Table 1. Pollen profile in samples and samples having the corresponding frequency class Sample $1 \quad$ Sample $2 \quad$ Sample 3 Sample 4

Apiaceae

Pimpinella sp.

M M

Asteraceae

Helianthus type

M

M M

Senecio type

Artemisia type

M

M

$\mathrm{M}$

Berberidaceae

$\mathrm{M}$

M

M

M

Berberis sp.

$\mathrm{T}$

$\mathrm{T}$

Betulaceae

Betula sp.

\section{$\mathrm{T}$}

Brassicaceae

Boraginaceae

M M

M

M

M

M

M

Echium sp.

Cistaceae

Cistus sp.

M

\section{Cupressaceae}

Juniperus sp.

\section{Fabaceae}

Astragalus sp.

M

Coronilla sp.

Glycyrrhiza sp.

Onobrychis sp.

S

Trifolium sp.

Vicia sp.

M

M

M

M

Fagaceae

Alnus sp.

Moraceae

Morus sp.

$\mathrm{T}$

Lamiaceae (6-colpate)

Juglandaceae

Juglans sp.

Primulaceae

Primula sp.

Ranunculaceae

Ranunculus sp.

M

Thalictrum sp.

\section{Rosaceae}

Sanguisorba sp.

Undetermined
M

$\mathrm{T}$
M

M

$\mathrm{T}$

M

$\mathrm{T}$

S

S

M 
In the present investigation, the commonly accepted assays HPSA, FICA, ABTS, FRAP and DPPH were used for the evaluation of antioxidant power of samples. Moreover, TPC and TFC were determined (Table 2). FICA and ABTS activity results of the samples are very close to each other. Therefore, comparisons between these activities of the samples were not considered appropriate. ABTS of the samples varied from 20.05 to $20.12 \mu \mathrm{g} / \mathrm{mL}$. In literature, a research group investigated the ABTS radical removal activities of Saudi Arabian honey samples as $0.36-1.2 \mu \mathrm{g} / \mathrm{mL}$ [23]. Their ABTS radical cation scavenging activity is higher than our result. In another study, ABTS radical cation scavenging activities of honey samples were determined in terms of SC50 as 54.33 $99.40 \mu \mathrm{g} / \mathrm{mL}$ and $10.33-41.20 \mu \mathrm{g} / \mathrm{mL}$ [24]. Alzahrani et al. (2012) investigated three types honeys and results ranged from 43.25-202.26 $\mu \mathrm{g} / \mathrm{mL}$ [25]. These results can be seen to be quite low compared to the results of our samples. ABTS radical cation removal activities of the standards we use are too small to be compared with our samples.

The FICA of samples was closely values, between 93.38 and $94.03 \%$. Temizer et al. (2018) were carried out three chestnut honeys' antioxidant activity. Their FICA results were determined as $36.7-36.9 \%$ [26]. Sherin et al. (2015) determined the metal chelation activities for honey samples as $54.2 \%$ [27]. These results are considerably lower than the FICA values of our samples. FICA results of the standard antioxidant substances we use were found lower than our samples.

The antioxidant capacity of ethanoic extracts of honey samples reacted with DPPH radical and was highly diverse SC50, from 54.45 to $387.60(\mu \mathrm{g} / \mathrm{mL})$. Salgueiro et al. (2014) found DPPH radical removal activities of eleven different honey samples in the range of 278.61-1601.8 $\mu \mathrm{g} / \mathrm{mL}$ [28]. Pontis et al. (2014) expressed DPPH radical scavenging activity of honey samples as $3170-$ $8790 \mu \mathrm{g} / \mathrm{mL}$ [29]. DPPH radical removal activities were found as $2.15-3.68 \mu \mathrm{g} / \mathrm{mL}$ in the study done in Saudi Arabian honey samples [30]. In another study, DPPH radical removal activities of honey samples were determined in the range of $29.388-458.450 \mu \mathrm{g} / \mathrm{mL}$. Yegin et al. (2018) found DPPH radical removal activities in the range of $76.50-275.48 \mu \mathrm{g} / \mathrm{mL}$ in nine multifloral honey samples. [31]. In another study, DPPH free radical removal activities of honey samples were determined in terms of SC50 as $54.33-99.40 \mu \mathrm{g} / \mathrm{mL}$ [24]. Sample 3 showed a DPPH radical scavenging activity at a level comparable to these results. DPPH radical removal activities of our standards were determined higher than our samples. 
Table 2. Biochemical profile of samples ( ${ }^{1} \mathrm{mg} \mathrm{GAE} / 100 \mathrm{~g},{ }^{2} \mathrm{mg}$ CAE $\left./ 100 \mathrm{~g},{ }^{3} \%,{ }^{4} \mathrm{SC}_{50} \mu \mathrm{g} / \mathrm{mL}\right)$

\begin{tabular}{llllllll}
\hline & TPC $^{\mathbf{1}}$ & TFC $^{\mathbf{2}}$ & FICA $^{\mathbf{3}}$ & HPSA $^{\mathbf{4}}$ & ABTS $^{\mathbf{1}}$ & DPPH $^{\mathbf{4}}$ & FRAP $^{\mathbf{3}}$ \\
\hline Sample 1 & 485.89 & 1.13 & 93.38 & 229.12 & 20.12 & 373.83 & 53.01 \\
Sample 2 & 370.96 & 3.30 & 93.86 & 213.06 & 20.05 & 387.60 & 47.20 \\
Sample 3 & 626.48 & 4.40 & 93.53 & 212.11 & 20.09 & 54.45 & 78.23 \\
Sample 4 & 225.24 & 1.26 & 94.03 & 246.64 & 20.12 & 330.58 & 54.15 \\
BHA & & & 84.25 & 72.05 & 193.27 & 8.42 & 8.47 \\
RUT & & & 86.80 & 92.66 & 122.98 & 15.54 & 16.90 \\
TRO & & & 69.44 & 53.04 & 445.06 & 4.18 & 26.74 \\
\hline
\end{tabular}

The results get from FRAP indicated large variability, from 47.2 to 78.23. In the literature, FRAP activities of three chestnut honey samples were determined between $71.30-73.70 \%$ [26]. In another study, FRAP activities were determined in a study with multifloral honey samples [31]. When we compare the FRAP activities of our standards with our examples, they were found quite low.

The HPSA of samples were slightly variety in terms of SC50, between 212.11-246.64 $\mu \mathrm{g} / \mathrm{mL}$. In the previously research, hydrogen peroxide scavenging activities of nine multifloral honey samples were found between $57.70-197.24 \mu \mathrm{g} / \mathrm{mL}$ [31]. In another literature, HPSA of three chestnut honey samples were determined as $252.0-258.6 \mu \mathrm{g} / \mathrm{mL}$ [26] According to these results, the HPSA values of our sample and the literature data are compatible. HPSA values of our samples are lower than the standards when compared with the standard antioxidant substances used.

The lowest phenolic content was detected in sample 4 while the highest in sample 3 (225.24 and $626.48 \mathrm{mg} \mathrm{GAE} / 100 \mathrm{~g}$, respectively). Silici and Ülgen (2019) determined TPC of eighteen honey samples as 70.60 - 212.06 mg GAE/100 g honey [32]. TPC of honey samples from Brazil were found as $25.00-54.80 \mathrm{mg} \mathrm{GAE} / 100 \mathrm{~g}$ [29]. Temizer et al. (2018) found TPC of honey samples between 93.80 - $173.20 \mathrm{mg} \mathrm{GAE} / 100 \mathrm{~g}$ [26]. Juszcak et al. (2016) argued that TPC of honey samples range from 21.73 to $50.12 \mathrm{mg} \mathrm{GAE} / 100 \mathrm{~g}$ [33]. Dżugan et al.,(2018) found TPC of samples $23.94-187.58$ $\mathrm{mg} \mathrm{GAE} / 100 \mathrm{~g}$ [34]. Yegin et al. (2018) determined TPC values between $26.57-184.85 \mathrm{mg}$ GAE/100 g [31]. Stagos et al. (2018) determined TPC of the honey samples between $55-92 \mathrm{mg}$ GAE/100 g [35]. TFC of ten monofloral honey samples obtained from Bangladesh ranged from 1.146 to $11.67 \mathrm{mg} \mathrm{CAE} / 100 \mathrm{~g}$ [36] . Temizer et al. (2019) determined that total phenolic and total flavonoid amounts of Ordu honeys varied from 32.5-171.05 mg GAE/100g [2]. Nayık and Nanda (2016) declared that TPC of Indian honey samples between 37 - $117 \mathrm{mg}$ GAE/100 $\mathrm{g}$ for 37 samples [37]. The mean value of TFC ranged from 1.13 to $4.4 \mathrm{mg} \mathrm{CAE} / 100 \mathrm{~g}$ of honey (Table 2). Yegin et al. 
(2018) declared that TFC of nine multifloral honey samples were $3.13-20.26 \mathrm{mg}$ CAE/100 g[31]. In another study, TFC of honey samples were found as $8-17 \mathrm{mg} \mathrm{QE} / 100 \mathrm{~g}$ [37]. Temizer et al. determined TFC of Ordu honeys as $1.65-38.75 \mathrm{mg}$ CAE/100g [2]. Temizer et al. (2018) found TFC of honey samples between $5.5-8.3 \mathrm{mg} \mathrm{CAE} / 100 \mathrm{~g}$ [38]. The TPC and TFC values obtained from our honey samples are compatible with the total phenolic and flavonoid substance contents of the honey samples studied in the literature. Temizer et al. (2020) studied five honey samples to determine the antioxidant activity and botanic origin. The antioxidant activity results of honey samples are compatible with our Bitlis honey samples [39].

As a result of the pollen analysis of honey samples, it was determined that Fabacae and Asteraceae families in the region are important food for bees. According to antioxidant test results, 4 honey samples showed different antioxidant activity due to their pollen components. Bitlis honey samples can be consumed to protect our health from endogenous and exogenous reactive species in normally produced in daily metabolic functions.

\section{REFERENCES}

1. Pasupuleti, V. R., Sammugam, L., Ramesh, N., Gan, S. H. (2017). Honey, Propolis, and Royal Jelly: A Comprehensive Review of Their Biological Actions and Health Benefits. Oxidative medicine and cellular longevity, 1259510-1259510.

2. Temizer, İ. K., Türkmen, Z., Güder, A. (2019). Assessment of Palynological Characterization and Total Phenol-Flavonoid Content of Some Honeys from Ordu in Turkey. 12(3), 1275-1282.

3. Dżugan, M., Sowa, P., Kwaśniewska, M., Wesołowska, M., Czernicka, M. (2017). Physicochemical Parameters and Antioxidant Activity of Bee Honey Enriched With Herbs. Plant Foods for Human Nutrition, 72(1), 74-81.

4. Temizer, İ. K., Güder, A., Çelemli, Ö. G. (2016). Botanic Origin, Various Physicochemical and Antioxidant Properties of Honey Samples From Giresun, Turkey. Hacettepe Journal of Biology and Chemistry, 44(3), 209-215.

5. Behçet, L. (1991). Süphan Dağ1 (Bitlis) Floras1. Yüzüncü Y1l Üniversitesi, Fen Bilimleri Enstitüsü Dergisi, 1(1), 29-38.

6. Altan, Y. Behçet, L. (1995). Hizan (Bitlis) Florası. Turk Journal of Botany, 19 (3 ), 331-344.

7. Altıo, A. (2004). Bitlis Çayı Havzası Florası, in Fen Bilimleri Enstitüsü. Yüzüncü Yı1 Üniversitesi.

8. Çelik, T. (2006). Kesan Deresi (Bitlis) Floras1, in Fen Bilimleri Enstitüsü., Yüzüncü Yı1 Üniversitesi. 
9. Keser, A. M. Özgökçe, F. (2019). The Flora of Karz (Garez) Mountain (Tatvan, Bitlis/ Turkey). Biological Diversity and Conservation, 12(2), 78-91.

10. Santos-Sánchez, N. F., Salas-Coronado, R., Villanueva-Cañongo, C., Hernández-Carlos, B., Antioxidant Compounds and Their Antioxidant Mechanism, in Antioxidants, E. Shalaby, Editor. 2019, IntechOpen: London.

11. Louveaux, J., Maurizio, A., Vorwohl, G. (1978). Methods of Melissopalynology. Bee World, 59(4), 139-157.

12. Song, X.-Y., Yao, Y.-F., Yang, W.-D. (2012). Pollen Analysis of Natural Honeys from the Central Region of Shanxi, North China. PLOS ONE, 7(11), e49545.

13. Gür, M., Güder, A., Verep, D., Güney, K., Özkan, O. E., Seki, N., Kandemirli, F. (2018). Some Important Plants for Epilepsy Treatment: Antioxidant Activity and Flavonoid Compositions. Iranian Journal of Science and Technology, Transactions A: Science, 42(4), 1847-1857.

14. Ateş, S., Gür, M., Özkan, O. E., Akça, M., Olgun, Ç., Güder, A. (2015). Chemical Contents and Antifungal Activity of Some Durable Wood Extractives vs. Pleurotus ostreatus. 2015, 10(2), 11.

15. Blois, M. S. (1958). Antioxidant Determinations by the Use of a Stable Free Radical. Nature, 181(4617), 1199-1200.

16. Ruch, R. J., Cheng, S.-j., Klaunig, J. E. (1989). Prevention of cytotoxicity and inhibition of intercellular communication by antioxidant catechins isolated from Chinese green tea. Carcinogenesis, 10(6), 1003-1008.

17. Dinis, T. C. P., Madeira, V. M. C., Almeida, L. M. (1994). Action of Phenolic Derivatives (Acetaminophen, Salicylate, and 5-Aminosalicylate) as Inhibitors of Membrane Lipid Peroxidation and as Peroxyl Radical Scavengers. Archives of Biochemistry and Biophysics, 315(1), 161-169.

18. Gökce, H., Alpaslan, Y. B., Zeyrek, C. T., Ağar, E., Güder, A., Özdemir, N., Alpaslan, G. (2019). Structural, spectroscopic, radical scavenging activity, molecular docking and DFT studies of a synthesized Schiff base compound. Journal of Molecular Structure, 1179, 205-215.

19. Oyaizu, M. (1986). Studies on products of browning reaction antioxidative activities of products of browning reaction prepared from glucosamine. The Japanese Journal of Nutrition and Dietetics, 44(6), 307-315.

20. Antonie, I. (2014). The biodiversity of the melliferous plants in the surroundings of the town sebes (alba county) and their economical importance Scientific Papers Series Management, Economic Engineering in Agriculture and Rural Development 14(4), 13-18.

21. Farkas, A. Zajacz, E. (2007). Nectar production for the Hungarian honey industry. The European Journal Plant Science and Biotechnology, 1(2), 125-151. 
22. Çelemli, Ö.G., Özenirler, Ç., Bayram, N. E., Zare, G., Sorkun, K. (2018). Melissopalynological analysis for geographical marking of Kars honey. Kafkas Universitesi Veteriner Fakultesi Dergisi, 24(1), 53-59.

23. Al-Hindi, R. R., Shehata, A. (2014). Evaluation of antioxidant and antibacterial activities and essential elements content of locally produced honey in Saudi Arabia. Life Science Journal, 11, 175-185.

24. Kıvrak, Ş., Kıvrak, İ. (2017). Assessment of phenolic profile of Turkish honeys. International Journal of Food Properties, 20(4), 864-876.

25. Alzahrani, H. A., Boukraa, L., Bellik, Y., Abdellah, F., Bakhotmah, B. A., Kolayli, S., Sahin, H. (2012). Evaluation of the antioxidant activity of three varieties of honey from different botanical and geographical origins. Global journal of health science, 4(6), 191-196.

26. Temizer, İ. K., Güder, A., Temel, F. A., Cüce, H. (2018). Antioxidant activities and heavy metal contents of Castanea sativa honey. Global NEST Journal, 20(3), 541-550.

27. Sherin, M. S., Benny, B., Ashadevi, S. (2015). Antioxidant Activity, DNA and Cellular Protective Effect of Honey from Srilanka. Asian Journal of Biochemistry, 10(3), 106-116.

28. Salgueiro, F. B., Lira, A. F., Rumjanek, V. M., Castro, R. N. (2014). Phenolic composition and antioxidant properties of Brazilian honeys. Quím. Nova, 37(5), 821-826.

29. Pontis, J. A., Costa, L. A. M. A. d., Silva, S. J. R. d., Flach, A. (2014). Color, phenolic and flavonoid content, and antioxidant activity of honey from Roraima, Brazil. Food Sci. Technol (Campinas), 34(1), 69-73.

30. Al-Hindi, R. R. Shehata, A. (2014). Evaluation of Antioxidant and Antibacterial Activities and Essential Elements Content of Locally Produced Honey in Saudi Arabia. 11(5), 175-185.

31. Yegin, S. Ç., Alver, D. O., Çiçek, F., Güder, A. (2018). Investigation of Antioxidant and Antimicrobial Activity of Different Multifloral Honeys. Mellifera, 18(2), 7-14.

32. Silici, S., Ülgen, N. (2019). Bioactive Properties of Blossom and Honeydew Honeys Mellifera, 19(2), 41-52.

33. Juszczak, L., Gałkowska, D., Ostrowska, M., and Socha, R., (2016). Antioxidant activity of honey supplemented with bee products. Natural Product Research, 30(12), 1436-1439.

34. Dżugan, M., Tomczyk, M., Sowa, P., Grabek-Lejko, D. (2018). Antioxidant Activity as Biomarker of Honey Variety. Molecules, 23(8): 2069.

35. Stagos, D., Soulitsiotis, N., Tsadila, C., Papaeconomou, S., Arvanitis, C., Ntontos, A., Karkanta, F., Adamou-Androulaki, S., Petrotos, K., Spandidos, D. A., Kouretas, D., Mossialos, D. (2018). Antibacterial and antioxidant activity of different types of honey derived from Mount Olympus in Greece. International Journal of Molecular Medicine 42(2), 726-734.

36. Moniruzzaman, M., Yung An, C., Rao, P. V., Hawlader, M. N. I., Azlan, S. A. B. M., Sulaiman, S. A., Gan, S. H. (2014). Identification of Phenolic Acids and Flavonoids in Monofloral Honey 
from Bangladesh by High Performance Liquid Chromatography: Determination of Antioxidant Capacity. BioMed Research International, 2014, 737490.

37. Nayik, G. A. Nanda, V. (2016). A chemometric approach to evaluate the phenolic compounds, antioxidant activity and mineral content of different unifloral honey types from Kashmir, India. LWT, 74, 504-513.

38. Temizer, İ. K., Güder, A., Temel, F. A., Avc1, E. (2018). A comparison of the antioxidant activities and biomonitoring of heavy metals by pollen in the urban environments. Environmental Monitoring and Assessment, 190(8), 462.

39. Temizer, İ. K., Güder, A., Başer, B. (2020). Botanic Origin and Antioxidant Activity of Some Bitlis Honeys. The Black Sea Journal of Sciences, 10(1), 121-130. 